\title{
Postoperative pain control in the elderly
}

\author{
F Calandese*, S Caroleo, B Amantea, E Santangelo \\ From de Senectute: Age and Health Forum \\ Catanzaro, Italy. 5-7 December 2009
}

\section{Background}

Older adults are a heterogeneous group but generally have a higher peak and longer duration of action from opioids. Monitoring cumulative effects from analgesics is particularly important for older adults [1].

Older adults should be first asked to describe their hurting or pain in their own words. Pain intensity should be measured with a consistent scale, after making sure that the individual understands the scale [2]. The pain thermometer, verbal description scale, and faces pain scale have all been used successfully with older adults, but older adults tend to have difficulty accurately reporting their pain with the 100-millimeter visual analog scale. Postoperative pain assessment during movement provides a more accurate pain measure than assessment at rest. Cognitively impaired older adults capable of verbal communication are generally able to report their pain and report pain intensity similar to cognitively intact individuals [3]. It might be necessary to try different pain scales if the older adult does not respond to the initial pain scale. Cognitively impaired older adults demonstrate more nonverbal pain behaviour on movement than those who are cognitively intact [4]. Family members can often identify behaviours indicative of pain in cognitively impaired older family members.

\section{Conclusions}

The elderly patient often presents with multisystem disease and changes in drug metabolism, elimination leading to increased sensitivity to analgesic medications. Even so, it is possible to provide these patients with good pain control by selecting the analgesic modality and drugs best suited to each individual patient. Using careful titration of analgesic doses, and by assessing patients frequently for inadequate pain control and for adverse side effects, elderly patients need not be denied

\footnotetext{
Unit of Anesthesia and Intensive Care, Magna Graecia University, Catanzaro,
} Italy the benefits of modern technology in the management of acute pain.

Published: 19 May 2010

\section{References}

1. Pain in the Elderly. IASP PressFerrell BR, Ferrell BA, 1996.

2. Chin ML: Postoperative pain management of the adult patient. IARS review Course Lectures 1996.

3. Liu S, Carpenter RL, Neal JM: Epidural anesthesia and analgesia, role in postoperative outcome. Anesthesiology 1995, 82:1474-1506.

4. Acute Pain Management: Operative or Medical Procedures and Trauma. Agency for Health Care Policy and Research (AHCPR) 1992.

doi:10.1186/1471-2318-10-S1-L54

Cite this article as: Calandese et al:: Postoperative pain control in the elderly. BMC Geriatrics 2010 10(Suppl 1):L54.
Submit your next manuscript to BioMed Central and take full advantage of:

- Convenient online submission

- Thorough peer review

- No space constraints or color figure charges

- Immediate publication on acceptance

- Inclusion in PubMed, CAS, Scopus and Google Scholar

- Research which is freely available for redistribution

Submit your manuscript at www.biomedcentral.com/submit
C Biomed Central 